Original Article

\title{
EFFECTIVENESS OF AN INFORM ATION BOOKLET ON HOME REMEDIAL MEASURES FOR BREAST ENGORGEMENT
}

\author{
Sherin Sara Eapen ${ }^{1} \&$ Philomena Fernandes ${ }^{2}$ \\ ${ }^{1}$ Lecturer, Hiranandani College of Nursing, M umbai, ${ }^{2}$ Associate Professor \& H.O.D, Department of Obstetrics \& \\ Gynaecological Nursing, Nitte Usha Institute of Nursing Sciences, Nitte University, Deralakatte, M angalore - 575018 \\ Correspondence \\ Philomena Fernandes \\ M obile : +9194492 07845, E-mail : philferns7@gmail.com
}

\begin{abstract}
:
The study was conducted to evaluate the effectiveness of an information booklet on Home remedial measures for breast engorgement among postnatal mothers. An evaluative approach with one group Pre test Post test design was used for the study. 40 samples were selected using simple random sampling method. The present study was conducted in Justice K.S. Hegde Charitable hospital Mangalore. The collected data were analysed using descriptive and inferential statistics. A significant difference between Pre test and Post test knowledge was found $(t=14.788, p<0.05)$. The study findings showed that the information booklet was highly effective in improving knowledge of the postnatal mothers by providing an information booklet on home remedial measures for breast engorgement. There was no significant association between the level of knowledge and demographic variables such as age, residing area, educational status, source of information, occupational status, parity.
\end{abstract}

Keywords : Home remedial measures, breast engorgement, Postnatal mothers.

\section{Introduction:}

Breast feeding is the most enriching experience for every mother; it plants the seeds of mother-child bonding. It is the most natural and, unique experience for every mother. It is a cherished and a learned art. Breast milk the "Cinderella substance of the decade" is nature's most precious gift to the newborn, and equivalent of which is yet to be innovated by our scientific community despite tremendous advances in science and technology. Just as there is no substitute for mother's love, there is no substitute for mother's milk. In an updated review on common problems during lactation and their management, it was found that breast engorgement is one among the several common problems that may arise during the breast feeding period and adequate $\mathrm{m}$ a $\mathrm{n}$ a ge men $\mathrm{t}$ is Access this article online Quick Response Code

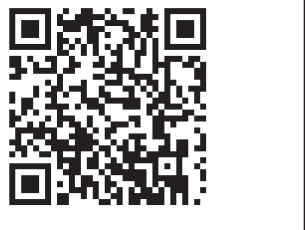

fundamental, if not treated will lead to early weaning. ${ }^{4}$

A descriptive study was conducted in Turkey on Women's problems when discharged early from the hospital after a normal vaginal birth, results revealed that breast engorgement was one of the most prevalent problem which constituted $71.4 \%(n=80){ }^{6}$ An informative resource by midwife, during short birth facility stays, play an inevitable role in preventing and managing feeding problems like breast engorgement. The education given in the early postnatal period is effective as the mothers are more receptive at this time to any information if it is contributing to the welfare of the child. Information booklet prepared by the researcher will impart knowledge to postnatal mothers on helpful and cost-effective home remedial measures for breast engorgement that can make breast-feeding, a rewarding and comfortable experience for the mother as well as the baby.

\section{Materials and Methods:}

An evaluative approach with one group pre test post test design was used for the study. 40 samples were selected randomly. Pre-test was administered to the participants who were admitted in the postnatal ward using structured knowledge questionnaire. The researcher collected the demographic data along with this. It took approximately $45 \mathrm{mts}$. After pretest researcher distributed the 
information booklet on home remedial measures for breast engorgement to the participants. After 5 days of intervention, the investigator administered the post test to assess the level of knowledge of mothers using the same structured knowledge questionnaire. The collected data were analysed using descriptive and inferential statistics.

\section{Results:}

M ain findings are discussed under the following headings

\section{SECTION 1: DESCRIPTION OF SAM PLE CHARACTERISTICS}

Distribution of postnatal mothers according to the demographic characteristics

I Distribution of mother's according to the age shows that highest percentage $47.5 \%$ (19) of mothers were in the age group of $24-29$ years, $27.5 \%$ (11) in the age group of $18-23$ years, $20 \%$ (8) were between $30-35$ years and $5 \%$ (2) were above 35 years of age.

I Residing area wise distribution of mothers reveals that $40 \%$ (16) mothers reside in urban area and $60 \%(24)$ mothers reside in rural area.

The educational status reveals that majority $40 \%(16)$ of them completed high school, $30 \%(12)$ completed primary school, $17.5 \%$ (7) completed PUC level, and $12.5 \%$ (5) of them were having an educational qualification of graduation and above.

I Source of information reveals that majority $60 \%$ (24) of the mothers availed information from family and friends, $25 \%$ ( 10 ) of the mothers received information from health professionals and $15 \%$ (6) got information from media.

I Occupation reveals that majority $82.5 \%$ ( 7) of them come under non-working category and $17.5 \%$ (33) of the postnatal mothers were working.

I parity reveals that $50 \%$ (20) were primiparous and $50 \%$ (20) were multiparous mothers.
SECTION II: KNOWLEDGE OF POSTNATAL M OTHERS ON HOME REM EDIALM EASURESFOR BREAST ENGORGEM ENT

Distribution of pretest knowledge scores of the mothers on home remedial measures for breast engorgement

\begin{tabular}{|c|c|c|}
\hline SCORE RANGE & FREQUENCY & PERCENTAGE \\
\hline Poor (0-16) & 14 & $35.0 \%$ \\
\hline Average (17-24) & 16 & $40.0 \%$ \\
\hline Good (25-32) & 9 & $22.5 \%$ \\
\hline Very Good (33-40) & 1 & $2.5 \%$ \\
\hline
\end{tabular}

The data presented in the table displays the frequency distribution of postnatal mothers according to their pretest knowledge scores. The data showed that $16(40 \%)$ had average knowledge score [score range 17-24], 14 (35.0\%) had poor knowledge [score range $0-16$ ],

9 (22.5\%) had good knowledge [score range 25-32] and 1 (2.5\%) had very good knowledge [score range $33-40$ ].

Area wise percentage of pretest and post test knowledge scores and gain scores of mothers.

\begin{tabular}{|c|c|c|c|c|c|}
\hline \multirow[t]{2}{*}{ SI.No } & \multirow[t]{2}{*}{ Areas } & \multicolumn{2}{|c|}{$\begin{array}{c}\text { Mean percentage } \\
\text { scores } \\
\end{array}$} & \multicolumn{2}{|c|}{ Gain scores } \\
\hline & & Actual & Modified & Pretest & Posttest \\
\hline 1. & $\begin{array}{l}\text { Definition, causes } \\
\text { \&symptoms }\end{array}$ & 83.12 & 94.37 & 11.25 & 0.671 \\
\hline 2. & Cabbage & 41 & 80.50 & 39.50 & 0.669 \\
\hline 3. & Massage & 56.25 & 81.25 & 25 & 0.571 \\
\hline 4. & Kangaroo M other Care & 39.16 & 87.50 & 48.34 & 0.794 \\
\hline 5. & hot $\&$ cold compress & 46 & 77.5 & 31.5 & 0.583 \\
\hline 6. & Jasmine flowers & 46.25 & 87.5 & 41.25 & 0.767 \\
\hline 7. & Other remedial measures & 46 & 70.83 & 24.83 & 0.459 \\
\hline
\end{tabular}

The data presented in Table 9 indicate that the post test mean percentage knowledge scores in all content areas were higher than the pretest mean percentage knowledge scores. The maximum post-test mean percentage score was in the area of definition, causes and symptoms. The data also shows that least modified gain was seen in the area of other remedial measures (0.459) and Kangaroo mother care which scored the lowest in pretest (39.16) demonstrated the maximum modified gain (0.794) which showed that information booklet on home remedial measures for breast engorgement was effective. 
SECTION III: EFFECTIVENESSOF INFORM ATION BOOKLET

M ean, M ean Difference, Standard error of Difference, and „t? ? value of pre-test and post test knowledge scores of postnatal mothers.

$n=40$

\begin{tabular}{|c|c|c|c|c|c|c|}
\hline & Mean & Mean & SD & Df & t value & $P$ value(LOS) \\
\hline Pretest & 19.95 & \multirow[t]{2}{*}{11.52} & \multirow[t]{2}{*}{4.950} & \multirow[t]{2}{*}{39} & \multirow[t]{2}{*}{14.788} & 0.000 \\
\hline Post test & 31.47 & & & & & $P \varangle 0.05 \mathrm{HS}$ \\
\hline
\end{tabular}

${ }_{\mathrm{t}}^{\prime}$ (tab) $39=2.021 \mathrm{p}<0.05$ level HS- Highly significant

The data in Table 10 shows that the mean post-test knowledge scores of postnatal mothers were significantly higher than their mean pretest knowledge scores ttab (39) $=2.021$, and calculated value $=t^{\prime}=14.788 p \varangle 0.05$. Hence research hypothesis was accepted.

Area-wise mean difference, standard deviation and 't' value of pretest and posttest knowledge scores. $n=40$

\begin{tabular}{|l|l|c|c|c|c|c|c|c|}
\hline & & \multicolumn{2}{|c|}{$\begin{array}{c}\text { Mean knowledge } \\
\text { scores }\end{array}$} & & & & \\
\hline SI.No & Areas & Pretest & Post-test & $\begin{array}{c}\text { Mean } \\
\text { difference }\end{array}$ & Df & $\begin{array}{c}\text { Standard } \\
\text { deviation }\end{array}$ & t value & P value \\
\hline 1 & Definition, causes \&symptoms & 3.32 & 3.77 & 0.45 & 39 & 0.78 & 3.63 & $.001 \mathrm{HS}$ \\
\hline 2 & Cabbage & 2.05 & 4.02 & 1.97 & 39 & 1.27 & 9.83 & $.000 \mathrm{HS}$ \\
\hline 3 & Massage & 2.25 & 3.25 & 1 & 39 & 1.13 & 5.58 & $.000 \mathrm{HS}$ \\
\hline 4 & Kangaroo M other Care & 1.17 & 2.62 & 1.45 & 39 & 0.90 & 10.14 & $.000 \mathrm{HS}$ \\
\hline 5 & Alternate hot \& Cold compress & 3.22 & 5.42 & 2.2 & 39 & 1.45 & 9.57 & $.000 \mathrm{HS}$ \\
\hline 6 & Jasmine flowers & 0.92 & 1.75 & 0.82 & 39 & .78 & 6.68 & $.000 \mathrm{HS}$ \\
\hline
\end{tabular}

't'tab (39) =2.021, $\mathrm{p} \varangle 0.05 \quad$ HS= Highly Significant

The data presented in the following tablell shows that the mean post-test knowledge scores of the postnatal mothers were significantly higher than the mean pre-test knowledge i.e. the $=1 \operatorname{tab}(39)=$ 2.021 which shows that the calculated value is greater than the table value $(p \varangle 0.05)$.This shows that there was significant gain in the knowledge in all the areas of home remedial measures for breast engorgement. Therefore the information booklet has been an effective method of increasing the knowledge of the mothers.

SECTION IV: ASSOCIATION BETWEEN PRETEST KNOWLEDGE SCORE AND SELECTED DEM OGRAPHIC DATA.

\begin{tabular}{|c|c|c|c|c|c|c|}
\hline Variables & $<$ median & $\geq$ median & $\chi^{2}$ value & $\chi_{\text {tab }}^{2}$ & df & LOS \\
\hline \multicolumn{7}{|l|}{ 1.Age } \\
\hline $18-23$ & 8 & 3 & \multirow[t]{3}{*}{4.257} & \multirow[t]{3}{*}{5.99} & \multirow[t]{3}{*}{2} & \multirow{3}{*}{$\begin{array}{c}0.119 \\
p>0.05 \mathrm{NS}\end{array}$} \\
\hline $24-29$ & 8 & 11 & & & & \\
\hline $30-35$ & 3 & 7 & & & & \\
\hline \multicolumn{7}{|l|}{ 2.Education } \\
\hline High School (8-10) & 15 & 13 & \multirow[t]{2}{*}{1.380} & \multirow[t]{2}{*}{3.8} & \multirow[t]{2}{*}{1} & \multirow{2}{*}{$\begin{array}{c}0.240 \\
p>0.05 \mathrm{NS}\end{array}$} \\
\hline Secondary School (PUC) & 4 & 8 & & & & \\
\hline \multicolumn{7}{|l|}{ 3.Source of information } \\
\hline Health information & 7 & 9 & \multirow[t]{2}{*}{0.150} & \multirow[t]{2}{*}{3.841} & \multirow[t]{2}{*}{1} & \multirow{2}{*}{$\begin{array}{c}0.698 \\
p>0.05 \mathrm{NS}\end{array}$} \\
\hline Family and friends & 12 & 12 & & & & \\
\hline \multicolumn{7}{|l|}{ 4.Parity } \\
\hline Primiparous & 10 & 10 & \multirow[t]{2}{*}{0.100} & \multirow[t]{2}{*}{3.841} & \multirow[t]{2}{*}{1} & \multirow{2}{*}{$\begin{array}{c}0.752 \\
p>0.05\end{array}$} \\
\hline Multiparous & 9 & 11 & & & & \\
\hline
\end{tabular}

The above table results that there is no significant association between the age, education, source of information, parity and knowledge level at 0.05 level of significance. 


\section{Conclusion:}

Application of home remedial measures for breast engorgement can be included as a nursing procedure to provide care during postnatal mothers with breast engorgement and also to update the knowledge on evidence based practices. The nurse administrator initiates the midwives to practice the application of home remedial measures to relieve breast engorgement through inservice education and continuing education programmes and also prepare written policies/protocol about evidence based practice. When nurses integrate the science and art of nursing into their practice, the quality of care provided to clients is at a level of excellence that benefits clients in innumerable ways.

The findings of the present study emphasize the management of breast engorgement with home remedial measures which can be put into nursing practice in relieving breast engorgement in postnatal mothers and

\section{REFERENCES}

1. Neely Melanie Curtis. Breastfeeding experiences of mothers using telehealth at one and four weeks postpartum. Journal of BSN Honors Research. 2010;1(1)

2. Stamp G E.Casanova H T.A breast feeding study in a rural population in South Australia. Rural and Remote Health. 2006;6:495

3. Margaret. Schmied Virginia. Sheehan Athena. An exploration of the relationship between postnatal distress and maternal role attainment, breast feeding problems and breast feeding cessation in Australia. Midwifery.2007;23(1):66-76

4. E R.Giugliani. Common problems during lactation and their management.J Pediat 2004; 80(5)147-54.

5. Balogun 0 R. Early Puerperal Complications: A Two Year Review in a Private Health Facility. The Nigerian Medical Practitioner. 2007; 51(3):36-39

6. Sebahat Gozum . Health problems related to early discharge of Turkish women. Midwifery 2005;21(4):371-378.

7. Bang A Rani . Maternal morbidity in labour and puerperium in rural homes and the need for medical attention: A prospective observational study in Gadchiroli, India. Available from URI: www.usaid.gov/our_work/global_health/.../morbidity_labour.doc

8. Hill Pamela D. Humenick, Sharron S.The Occurrence of Breast Engorgement. The journal of human lactation.1994;10(2):79-86

9. Mallikarjuna H.B.Banapurmath C.R. Banapurmath. Shobha. Kesaree Nirmala. Breast feeding problems in first six months of life in rural Karnataka. Indian Pediatrics.2002; 39(9):861-864

10. Parker E.M.Nursing theories and nursing practice.2nd edition. Philadelphia:Jaypee Brothers; 2007.

11. George .M.J.Nursing theories the base for professional nursing practice.4th edition.Norwalk. Library of congress.1995.

12. Arora Smriti, Vatsa M anju, Dadhwal Vatsla. A comparison of cabbage leaves vs. hot and cold compresses in the treatment of breast engorgement. Indian journal of community medicine.2008; 33(3)

13. Ruba.A.Effectiveness of cabbage leaves application to relieve breast engorgement. Nightingale Nursing Times. 2009; 5(9):48-51.

14. H M Snowden, M J Renfrew, M W Woolridge.Treatments for breast encourage mothers to work with practical knowledge.

Breast engorgement being one of the major problem among the breast feeding mothers and a reason for giving up feeding in the first two weeks, nurses and midwives can be trained to include home remedial measures for breast engorgement in their discharge teaching. The findings of present study can be utilized by nurse researchers to contribute to the profession to accumulate new knowledge regarding breast engorgement and its management, and can take professional accountability to educate and motivate postnatal mothers towards health promoting practices. The present study would help nurses and other healthcare personnel to understand the level of knowledge of postnatal mothers regarding management of breast engorgement using home remedial measures. Based on this knowledge nurse researchers can undertake similar studiesamong postnatal mothers.

engorgement during lactation. Cochrane Database Syst Rev .2001; 18(2) Roberts L Kathryn. A Comparison of Chilled Cabbage Leaves and Chilled Gel packs in Reducing Breast Engorgement. Journal of human Lactation. 1995; 11(1):17-20

15. Nikodem V C, Danziger D, Gebka N, Gulmezoglu A M , Hofmeyr G J. Do cabbage leaves prevent breast engorgement? Birth.1993; 20(2):61-4.

16. Munns Alison. Cabbage leaves can help inflammation of any body part. BM .2003;327(7412): 451

17. Lauwers Judith, Swisher Anna. Counseling the nursing mother: a lactation consultant's guide.Canada.J ones \& Barlett publishers; 2010.

18. Storr, G. B. (1988), Prevention of Nipple Tenderness and Breast Engorgement in the Postpartal Period. Journal of Obstetric, Gynecologic, \& Neonatal Nursing .2006; 17(3):203-209.

19. Hamilton Health Sciences. Breast Engorgement. February 21, 2005.

20. Varney Helen, Kriebs M Jan., Gegor L.Carolyn. Varney's Midwifery.Canada.Jones and Barlett. Publishers.2004.

21. Su-Zhao Pan, Qin Zhao. A Comparison of the Breast Distension Relieving Effects of Two Massage Manipulations. Journal of nursing 2009-08

22. Vincent Harrison. The Newborn Baby. South Africa.Juta \& company Itd.2008.

23. Elsa R. J. Giugliani. Common problems during lactation and their management. Jornal de Pediatria 2004;80(5)

24. Hill D Pamela. Association of Serum Prolactin and Oxytocin with Milk Production in Mothers of Preterm and Term Infants. Biological Research for Nursing.2009; ].000(00)

25. Riordan Jan .Breastfeeding and human lactation. London.Jones and Barlett publishers; 2005

26. Moore ER, Anderson GC, Bergman N. Early skin-to-skin contact for mothers and their healthy newborn infants. Cochrane Database of Systematic Reviews.2007 (3)

27. KM izuno, N M izuno, T Shinohara, M Noda. M other-infant skin-to-skin contact after delivery results in early recognition of own mother's milk odor. Acta paediatrica .2004; 93(12):1560-2.

28. Righard L. Alade M. O. Effect of delivery room routines on success of 
first breast-feed. The Lancet. 1990; 336(8723): 1105-1107

29. Anderson GC, Moore E, Hepworth J, Bergman N.Early skin-to-skin contact for mothers and their healthy newborn infants. Cochrane Database of Systematic Reviews 2003(2).

30. Moore .R. Elizabeth. Anderson Cranston Gene. Randomized Controlled Trial of Very Early M other-Infant Skin-to-Skin Contact and Breastfeeding Status. Journal of M idwifery \& Women's Health.2007; 52(2):116-125

31. Bramson Leslie. Effect of Early Skin-to-Skin M other-Infant Contact during the First 3 Hours Following Birth on Exclusive Breastfeeding during the M aternity Hospital Stay. Journal of human lactation. 2010; $26(2)$ :

32. Knight K L.Cryotherapy in sport injury management. USA.Library of congress.1995.

33. Kellogg Harvey John. Rational Hydrotherapy Vol.2. Kessinger Publishing, 2003
34. Goldberg Burton, Trivieri Larry, W. Anderson John. Alternative medicine: the definitive guide. Celestial Arts, 2002.

35. Bompa O Tudor, Haff Greg. Periodization: Theory and M ethodology of Training.USA. Human Kinetics, 2009.

36. Anne Beverley Robson.Breast engorgement in breastfeeding mothers [Dissertation]. Case Western Reserve University, Nursing, 1990.Available from URL: http://etd.ohiolink.edu/view.cgi?acc_num $=$ case1054750626.

37. M artin Ingrid. Aroma therapy for massage practitioners. Philadelphia. Lippincott Williams \& Wilkins.2010.

38. Shrivastav P, George K, Balasubramaniam N, Jasper MP, Thomas M, Kanagasabhapathy AS. Suppression of puerperal lactation using jasmine flowers (Jasminum sambac). The Australian \& New Zealand journal of obstetrics \& gynecology .1988; 28(1):68-71

39. Abraham M .Devi N S.Sheela R. Inhibiting effect of jasmine flowers on lactation. Indian J ournal of M edical Research. 1979;69:88-92 